\title{
Violence at School and Its Root Cause
}

\author{
$1^{\text {st }}$ Tuti Budirahayu \\ Faculty of Social and Political Science \\ Universitas Airlangga \\ Surabaya, Indonesia \\ tuti.budirahayu@fisip.unair.ac.id
}

\author{
$2^{\text {nd }}$ Novri Susan \\ Faculty of Social and Political \\ Science \\ Universitas Airlangga \\ Surabaya, Indonesia \\ novri.susan@fisip.unair.ac.id
}

\begin{abstract}
Violence experienced by the students has become well-known phenomenona in Indonesia. Violence cases are commited by varios education actors among teachers and students. The main purpose of this study is to highlight a wide range of forms of violences and picture the student's perception. In addition, the study also aims to examine the variables which causing the violence in schools. To further explore the research problem, the study uses a descriptive quantitative approach done by conducting observation and survey to 400 students done in four cities. The results show a high number of students who have experienced violence/bullying at school. Students and teachers can be both perpetrators and victims. The findings of this research has identified forms of violence that include (1) physical violence; (2) indirect violence; (3) verbal violence while the causes of violence vary from (1) the interaction actors in school, and (2) unconducive academic environment at school.
\end{abstract}

Keywords-violence, student, senior high school, academic environment, social interaction

\section{INTRODUCTION}

The coverage of violent cases among student is often shown in various mass media. The cases of violence that involving the teachers when punishing their students or senior students who want to 'discipline' their juniors, or the fighting between the student themselves until the physical violence happened because of trivial matters. The conflict that leads to violence-whether committed by the teachers to students, or between students themselves can occur due to the unbalanced relationships between the perpetrators of violence and their victims.

Various forms of violence reported by by the Indonesian Child Protection Commission (KPAI) show that the tendency of violence on children and adolescents did not only occur within the family environment but also at schools. In 2007 it was noted that there were 555 cases of violence experienced by Indonesian children, where 18 percent of the perpetrators were the closest relatives. Interestingly, there were 11.8 percent among perpertrators were teachers [1]. Another striking note from this report is the location of child abuse that takes place in home and school [2].

The violence experienced by students could result in psychological and sociological impacts on them. For example, the students might become less confident, desperate, alienated, or even being emotional to their surroundings due to trauma and negative perceptions attached on them. It is very common that bullied students will create troubles even commit criminal acts.

This study aims to highlight the forms of violence experienced by the students in schools and their root cause gained by their perception regarding the act of violence.

\section{RESEARCH METHOD}

This study utilizes explanative approach. Data collection is done by conducting observation and survey among secondary schools, including the vocational ones in four cities in East Java. Data sampling is taken randomly by asking 400 students from eight different schools. Later, the data will be analyzed by descriptive statistics and cross tabulation on a number of variables.

\section{RESEARCH FINDINGS}

This section explains the research findings as well as analyze the relationships between the variables that are used to observe the violence that experienced by the students at schools which related to the academic atmosphere in the schools.

The respondents who targeted for this study were secondary school students with age ranges from 15 to 18 years old, for 59 percent aged 15-16 years old, and 41 percent aged between 17 to 18 years old. The number of female respondents was more (53 percent) than the male respondents ( 47 percent).

\section{A. Respondents Characteristics}

This research observes that there is a percentage of students who have experienced violence at school that reached 65.5 percent. The locations of violence generally takes place within school environment (42.4 percent), specficailly in the classroom (26.7 percent). Relatively high number of students experiencing violenece outside school also occurs by 30.9 .

Violence in schools seems commonly done in all regions. One of the types of violence can be referred as bullying, that according to Bieber [3] quoting Olweus is an aggressive behavior which repeatedly intended to hurt the victim, because of the unbalanced relationship between the victim and the offender. The fact that school is a common location where 
violence/bullying occured is nothing new if we look at previous study, for examples, Ama and Naito [4] cited in Rigby as well as Rivers \& Soutter.

\section{B. The Perpetrators and Types of Violence}

If more violence occurs in school environments, then, it becomes important to know who are the violence perpetrators that experience by the students at the school. The table below depicts the trend from the violence perpetrators which according to students' experiences.

TABLE I. Violence PERPETRATORS AT SCHOOL $(\mathrm{N}=400)$

\begin{tabular}{|l|c|c|c|}
\hline $\begin{array}{l}\text { Violence } \\
\text { Perpetrators }\end{array}$ & Yes & No & TOTAL \\
\hline $\begin{array}{l}\text { Between } \\
\text { the Students }\end{array}$ & $\begin{array}{c}329 \\
(82,25 \%)\end{array}$ & $\begin{array}{c}71 \\
(17,75 \%)\end{array}$ & $\begin{array}{c}400 \\
(100 \%)\end{array}$ \\
\hline Teachers & $\begin{array}{c}177 \\
(44,25 \%)\end{array}$ & $\begin{array}{c}223 \\
(55,75 \%)\end{array}$ & $\begin{array}{c}400 \\
(100 \%)\end{array}$ \\
\hline $\begin{array}{l}\text { School Administration } \\
\text { Staff }\end{array}$ & $\begin{array}{c}28 \\
(0,49 \%)\end{array}$ & $\begin{array}{c}327 \\
(81,75 \%)\end{array}$ & $\begin{array}{c}400 \\
(100 \%)\end{array}$ \\
\hline
\end{tabular}

Based on Table 1, it is seen that the most perpetrators of violence are the cause of conflict among students ( 82.25 percent), while the violence by teachers to their students amounted to less around 44.25 percent. Therefore, it can be said that the violence conducted by the teachers to students is much smaller compared to the violence that done by the students themselves.

\section{Types and Perception Index of Violence}

The types of violence explained in this study use the violence dimension that proposed by Robert F. Litke [5] which includes both personal and institutional dimensions, as well as physical and psychological. Personal-psychological dimension including (1) physical violence (direct) either by using a tool or not with the aim to attack the targeted person body such as: beating or torturing; and (2) personal psychological violence in a verbal form such as verbal abuse, scolding, anger or sarcasm. While, violence in the institutional dimension covers: (1) indirect violence: actions that endanger humanity, such as riots, terrorism, or war and death threats; (2) repressive violence, which the form of violence that relates to the violation of basic human rights besides the right to survive and the right to be protected from torments or suffers; and (3) alternative violence refers to the deprivation of individual human rights, such as the rights to emotional, cultural, or intellectual growth.

In an attempt to simplify Litke's thought, thus, there are four categorizations of violence, those are: physical, verbal or non-physical, indirect, (being threatened, intimidated, blackmailed, or slandered) and repressive (related to the eradication people human rights, disregarded by the institution, unprotected and did not receive medical treatment if sick). The following data illustrates the types of violence that experienced by the respondents.
TABLE II. CATEGORIES OF VIOLENCE THAT EXPERIENCED BY THE STUDNETS $(\mathrm{N}=400)$

\begin{tabular}{|l|l|l|l|}
\hline $\begin{array}{l}\text { Categories of } \\
\text { Violence }\end{array}$ & Yes & No & Total \\
\hline $\begin{array}{l}\text { Physical Violence (by } \\
\text { using the tools or not) }\end{array}$ & $\begin{array}{l}342 \\
(85,5 \%)\end{array}$ & $58(14,5 \%)$ & $\begin{array}{l}400 \\
(100 \%)\end{array}$ \\
\hline $\begin{array}{l}\text { Verbal Violence/non } \\
\text { physical }\end{array}$ & $\begin{array}{l}378 \\
(94,5 \%)\end{array}$ & $22(5,5 \%)$ & $\begin{array}{l}400 \\
(100 \%)\end{array}$ \\
\hline Indirect Violence & $\begin{array}{l}278 \\
(69,5 \%)\end{array}$ & $\begin{array}{l}122 \\
(30,5 \%)\end{array}$ & $\begin{array}{l}400 \\
(100 \%)\end{array}$ \\
\hline Repressive Violence & $112(28 \%)$ & $288(72 \%)$ & $\begin{array}{l}400 \\
(100 \%)\end{array}$ \\
\hline
\end{tabular}

Table 2 pictures that students have experienced varoious kinds of violence, with verbal (94.5\%) and physical (85.5\%) violence dominating. While indirect violence was experienced by almost 70 percent of respondents, and who said they had experienced or knew repressive violence was only 28 percent.

The students' perception about which one of the violence is identified more detail in Table 3 . Calculation of this perception violence index is by putting the score in each form of violence from the impact which perceived as the most severe and the lightest.

TABLE III. RECAPITULATION ON VIOLENCE PERCEPETION INDEX BASED ON THE HIDH SCORE $(\mathrm{N}=400)$

\begin{tabular}{|l|l|l|l|}
\hline No. & Form of Violence & Index & $\begin{array}{l}\text { Violence } \\
\text { Category }\end{array}$ \\
\hline 1. & Hit with tools & 295 & Physical \\
\hline 2. & Hit with hands & 230 & Physical \\
\hline 3. & Slandered & 230 & Indirect \\
\hline 4. & Gossiped & 215 & Indirect \\
\hline 5. & Reviled & 195 & Verbal \\
\hline 6. & Threatened/Intimidated & 190 & Indirect \\
\hline 7. & Insinuated & 180 & Verbal \\
\hline 8. & Pinched & 160 & Physical \\
\hline 9. & Scolded & 140 & Verbal \\
\hline 10. & Nagged & 135 & Verbal \\
\hline 11. & Kick & 130 & Physical \\
\hline 12. & Harassed & 105 & Indirect \\
\hline 13. & Ignored & 85 & Repressive \\
\hline 14. & Unprotected & 65 & Repressive \\
\hline 15. & Blackmailed & 40 & Indirect \\
\hline
\end{tabular}

The form of violence that is perceived as the most severe according to the respondent is physical violence (beaten by tools or hand), then the second position is indirect violence (slandered or gossiped). While the verbal violence such as reviling and intimidated. Some of the most severe forms of-of repressive violence is being ignored within the group and unprotected by the government. Based on the violence index, it can be said that besides direct violence (physical and verbal), indirect violence is also regarded as something that is painful for high school students, although their physical body was not traumatized or injured. However, psychological trauma may even be regarded as something more hurtful.

\section{Causing Factors of Violence in School}


The following description is a cross-tabulation analysis of some variables that may be related to the student's experience when knowing or receiving various forms of violence during at school

i. The relationship in the interaction and teacher attention towards the students with the violence that experienced by the students at the school

There is a lot of argument about the causes of violence in schools, especially when the teachers abuse their students. The arguments can be categorized from three sides [6]. The first side, the teacher sees the students weaknesses, where students' attitudes and behaviors are judged to be too obscene, therefore with their legitimacy, the teachers use violence to students to subdue the students' inappropriate behavior. The second side, the violence that happened towards the student is seen as a result of the teacher weakness.

The cause of violence against the students can occur because the teachers do not understand the meaning of violence itself and its negative consequences. There are abundant teachers who think that by punishing the students, they will be deterred and would not repeat the mistakes. However, from the student side, the impact of violence will be much different. It even makes the student can hate their teacher and would be less respect for their teacher. The third side, the student's violence happened is because of the weakness from the learning systems and methods, including the shortcoming of educational institutions which produce the teachers as well as the institutions that authorized and determine the content and curriculum education.

Greydanus et al. [7] note that the violence in education is a promotion of the wrong message. This has an impact on the teacher's attitude who tend to use violence to discipline their students. Where it is also because of the previous example of authority figures or parental replacement role who often use violence. Teachers who consider violence as a way to discipline their students, tend to think that violence is a natural and acceptable thing.

The society also considers violence as a means to discipline young people so that they are willing to obey the existing rules. With such an assumption, therefore, it is natural when the teachers use violence to follow the example of authority figures in the society. In addition, the teachers seem to have the authority from the students' parents to subdue their children, and for them, it is reasonable for the teacher to do the violence since that they also experienced the same thing.

The following data shows the relationship between the intensity of the teacher-student interaction with whether or not the students ever experienced the violence in school.
TABLE IV. THE INTERACTION BETWEEN THE TEACHERS AND STUDENTS AND THE VIOLENCE EXPERIENCED BY THE STUDENTS $(\mathrm{N}=400)$

\begin{tabular}{|l|c|c|c|}
\hline $\begin{array}{l}\text { Whether or not ever } \\
\text { experiencing } \\
\text { violence (Y) }\end{array}$ & \multicolumn{3}{|c|}{ The interaction between the teachers and } \\
students (X1)
\end{tabular}

Based on Table 4. it can be seen that respondents who experienced violence in school have a less friendly relationship with their teacher (73.5 percent), although there is about 54.6 percent of respondents who claim to be friendly with the teacher they also experienced the violence. Based on the two variables analysis, shows that the interaction between teachers and students to a certain degree affecting the occurrence of violence that experienced by the students in school. Proper interaction between teachers and students can make the learning atmosphere more conducive and fun. Conversely, if the interaction between teachers and students are not on good terms, then the students will feel neglected, and it could trigger various negative behavior with the student self.

Besides the interaction intensity between the teachers and students, the other things that could affect the actions and behaviors of the students at the school are the teacher's attention towards the students. Based on the analysis of those two variables, it was found that the respondents who felt that their teachers did not give sufficient attention to them, they had experienced violence in school (76 percent). Although there was about 53.6 percent of students admitted that they have received attention from their teachers, however, they also experienced the violence. As a result, it can be said that the intensity of interaction and attention from the teachers to their students have an effect on the occurrence of violence that experienced by the students in school.

Fair attention from the teacher to their students actually become one way for the teachers in helping to find out the students problems, both in academic and non-academic matters. The attention given by the teacher to the students can also reduce the problems or conflicts that could arise between them or even between the students themselves.

ii. The relationship between the interaction and seniority system between the students at the school with the violence that experienced by the students

The interaction between peers can also trigger the violence that experienced by the students. If their friendship is less friendly, then most likely they will 
be hostile to each other until they fight with each other.

According to the data analysis on the relationship between students interactions and the violence experienced by students in school, the results shows that the respondents whose relationships are less friendly with their friends tend to experience more violence in school (71.4 percent), although there are about 59.3 percent respondents who claim to be friendly with their friends they have also experienced violence in school.

This means that although the interaction between the students is quite friendly, it does not guarantee that they have never experienced conflict or violence in school. The dynamics of interaction between students shows both harmony and disintegration tendencies. While different results happened when the seniority systems in schools are considered to be variables that affect the experience of violence among students. Based on the analysis the relationships between those variables indicates that when the seniority system occurred, it was quite a lot of students had experienced violence in school (77.3 percent). In contrast, when the schools do not have a seniority system, 45.2 percent of respondents claimed they never experienced the violence.

TABLE V. THE EXISTENCE OF SENIORITY SYSTEM CONNECTED TO THESTUDENTS VIOLENCE AT SCHOOL $(\mathrm{N}=400)$

\begin{tabular}{|l|c|c|}
\hline \multirow{2}{*}{$\begin{array}{l}\text { Whether or not ever } \\
\text { experiencing violence } \\
\text { Y) }\end{array}$} & \multicolumn{2}{|c|}{$\begin{array}{c}\text { The Existence of Seniority System } \\
\text { (X2) }\end{array}$} \\
\cline { 2 - 3 } & Yes & No \\
\hline Yes & $92(77,3 \%)$ & $\begin{array}{c}154 \\
(54,8 \%)\end{array}$ \\
\hline No & $27(22,7 \%)$ & $\begin{array}{c}127 \\
(45,2 \%)\end{array}$ \\
\hline Total & $119(100 \%)$ & $\begin{array}{c}281 \\
(100 \%)\end{array}$ \\
\hline
\end{tabular}

The seniority system is a subordination mechanism from senior students to their juniors. The purpose of this system is because they want to be respected, appreciated, followed or even feared by junior students. The term seniority itself is a higher state of rank, experience, and age or priority status derived from the age or duration of work/schooling. The term seniority implies that there has been a suppressive behavior that done the by the senior to their junior.A seniority term is an act of seniors who want to be respected by their junior. This situation will be an opportunity for the oppression or acts of violence committed by senior to their junior. Based on the data analysis above, it can be said that the seniority system, has a significant influence on violence experienced by the respondents in the school. A study conducted by Usman [8] to some students at Gorontalo High School also shows that seniority in school is a phenomenon that causes bullying in which junior students become the victims due to the imbalanced relationship between them.

\section{iii. The relationship between the Availability of Extra Curricular Activities with Violence experienced by students in schools.}

Various activities that able to support student learning, such as group learning, extra-curricular activities, youth activities at school mosques, Intra School Student Organization (OSIS) activities, art performances, exhibitions, and student competitions which these activities can support the student learning at school. If such activities are not available, then the students may be bored. If their boredom is not neutralized with those activities, then the probability that students will look for other activities outside the school that may lead to negative activities becomes higher. Such fights between students, both in school and outside the school environment.

Based on the analysis results between the variables in extra-curricular activities and the violence experienced by students, it is shown that the absence of extra-curricular activities tends to cause students to experience violence in school (71 percent), although 57 percent of respondents admitted that although they actively involved in extracurricular activities they still experienced violence in school.

TABLE VI. AVAILIBILITY OF EXTRA CURRICULAR ACTIVITIES WITH VIOLENCE EXPERIENCES BY STUNDENTS IN SCHOOLS $(\mathrm{N}=400)$

\begin{tabular}{|l|c|c|}
\hline $\begin{array}{c}\text { Whether or not ever } \\
\text { experiencing } \\
\text { violence in School }\end{array}$ & \multicolumn{2}{|c|}{$\begin{array}{c}\text { The availability of extracurricular } \\
\text { activities in School (X3) }\end{array}$} \\
\cline { 2 - 3 } & Available & Not Available \\
\hline Yes & $156(57 \%)$ & $90(71 \%)$ \\
\hline No & $118(43 \%)$ & $36(29 \%)$ \\
\hline Total & $274(100 \%)$ & $126(100 \%)$ \\
\hline
\end{tabular}

Based on the data analysis of the two variables in Table 6., it can be said that various kinds of extracurricular activities at school also help to reduce the occurrence of violence experienced by students. This is in line with the studies conducted by Dake, Price, and Telljohann [9] which show that students who tend to engage in bullying are generally less involved in positive activities at school. They tend to be difficult to make adjustments, such as unable to follow activities and do the tasks well, lack of happiness with the activities at school.

iv. The relations between the Availability of School Facilities with Violence that experience by the students

Adequate learning facilities at schools are needed in order for the process of learning and teaching are going well. A proper educational facility could support comfortable and enjoyable learning activities. It is because those facilities is a way to create a suitable atmosphere for the students to 
perform their activities at school. If the learning facilities are inadequate, then the consequence could lead to the student's inability to learn effectively because of the minimum facilities which can be used both by the students and teacher in the classroom. If such conditions continue to happen then the students no longer interest in studying and tend to seek outof-school activities, even interacting with other friends who give negative influence. The following is the analysis of the availability of educational facilities which linked to the occurrence of violence in schools.

TABLE VII. The AVAILIBILITY OF AdEQUATE EdUCATION FACILITIES LINK WITH THE VIOLENCE THAT EXPERIENCED BY THE STUDENTS AT SCHOOL $(\mathrm{N}=400)$

\begin{tabular}{|l|c|c|}
\hline $\begin{array}{l}\text { Whether or not ever } \\
\text { experiencing violence } \\
\text { in School }\end{array}$ & \multicolumn{2}{|c|}{$\begin{array}{l}\text { The Availability of Adequate } \\
\text { Educational Facilities at School (X4) }\end{array}$} \\
\cline { 2 - 3 } & Available & Unavailable \\
\hline Yes & $112(49 \%)$ & $134(77,5 \%)$ \\
\hline No & $115(51 \%)$ & $39(22,5 \%)$ \\
\hline Total & $227(100 \%)$ & $173(100 \%)$ \\
\hline
\end{tabular}

Based on the analysis of the two variables above, it can be seen that the 77.5 percent of respondents had ever experienced the violence are in the inadequacy of educational facilities in school condition. By contrast, as many as 51 percents of respondents who claimed that the educational facilities in schools are adequate they never experienced the violence. Taking into account of the cross-table analysis results, it can be said that the availability of adequate learning facilities is needed to support a conducive atmosphere for students and the chance for the students to do negatives activities or engage in conflicts can be reduced.

The students who are living with a good learning atmosphere, tend to spend more time by doing positive things, such as working, doing their schoolwork, or engaging intra- and extra-curricular activities which beneficial to their talent development and potential. The studies conducted by Boswell [11] show that the school atmosphere is one of the major causes of violence and bullying by students in schools. Boswell quotes Cook, Williams, Guerra, Kim, and Sadek states the meaning of good learning atmosphere is measured by the level of respect and fair treatment towards the students by the teachers and school administrators. Besides they also have a sense of belonging to the school. Boswell also cites the opinions of Voight, Austin, and Hanson that broaden the meaning of school atmosphere that includes: order, security, discipline, students' academic support, personal relations and social relationships, adequate school facilities, and the attachment from all the school members' towards the school.

\section{CONCLUSION}

This study has found acts of violence or bullying conducted in education environments both inside and outside schools. The penetrators and victims can be students and teachers, doing several kinds of acts including verbal and physical abuse as well as indrect and represive violence.

After examining a wide range of factors that cause such acts, schools need to enhance more comfortable and enjoyable learning activities. These circumstances should be able to support the needs of the sudents facilitated by infarstructures that might increase more positive activities in schools. To prevent and eradicate violence and bullying in education environment in the future, education stakeholders should pay more attention to several factors that become the trigger of negative acts such as interaction between teachers and students, seniority system in schools, and uncomfortable and unenjoyable learning process.

\section{REFERENCES}

[1] Ade Fadli. (Violence toward Student in School) "Kekerasan Terhadap Anak di Sekolah," [Online]. Avalaible: http://timpakul.web.id/pendidikan-9.html.

[2]Wijoseno, Gagah, (A Student was Beaten by the Teacher) "Siswa Dihajar Guru," Detik Surabaya. [Online] Avalaible: Detikcom.

[3]Bieber, Kristin.E, "Do Students Understanding What Researchers Means by Bullying?", A Dissertation at University of NebraskaLincoln, 2013

[4]Ama, Shoko Yoney \& Asao Naitu, "Problems with the Paradigm: the School as a Factor in Understanding Bullying (with Special Reference to Japan)" , British Journal of Sociology of Education, Vol.24, No.3 (Jul., 2003) pp 315-330.

[5]Litke, Robert, F, "Violence and Power in Thinking about Violence Perspectives from Philosophy, History, Psychology, and Sociology", England: Blackwell Publishers/UNESCO, 1992

[6]Indarwanto, Eko, (Violence in Indonesian Education) "Kekerasan dalam Pendidikan di Indonesia," [Online]. Avalaible: http://sayapsikologi2006.blogspot.com/2010/01/kekerasandalam- pendidikan-di-Indonesia.html.

[7] Greydanus E, Donald, (Violence in Education of Indonesia) "Kekerasan Dalam Pendidikan di Indonesia," [Online]. Available:

http://sasyapsikologi2006.blogspot.com/2010/01/kekerasadalam-pendidikan-di-indonesia.html.

[9] Usman, Irvan, (Personality, Communication, Peer Group, School Environment, and Bullying Behaviour) "Kepribadian, Komunikasi, Kelompok Teman Sebaya, Iklim Sekolah dan Perilaku Bullying," Humanitas, Vol X, No.1 January 2013.

[10] Dake, Joseph A, James H. Price, Susan K. Telljohann, "The Nature and Extent of Bullying at School", The Journal of School Health; May 2003; 73, 5; Health \& Medical Collection, pg. 173

[11]Boswell, M.Alison,"School Level Predictors of Bullying Among High School Students", Theses and Dissertations-Educational, School, and Counseling Psychology (2016) [Online]. Avalaible: 44.http://uknowledge.uky.edu/edp_etds/44. 